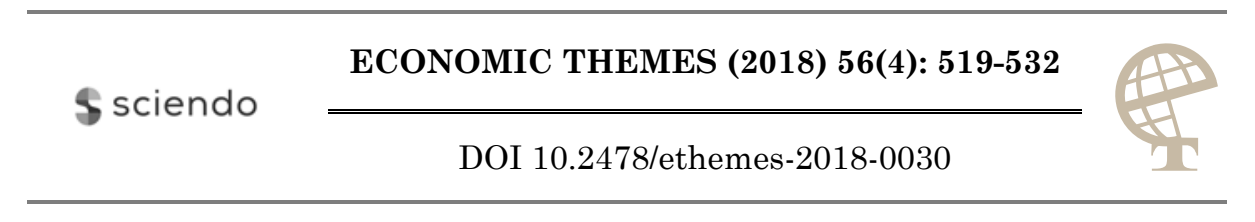

\title{
DIFFERENCES IN INWARD FDI PERFORMANCE BETWEEN THE SOUTHERN EUROZONE AND EASTERN EU MEMBERS: A PANEL-DATA ANALYSIS OVER 2004-2016
}

\author{
Klimis Vogiatzoglou
}

ALPHA Corporate Training and Consulting, Athens, Greece

$\triangle$ klimis.vogiatzoglou@gmail.com

College of Management, NSYSU, Kaohsiung, Taiwan

$\checkmark$ vogiatzoglou@cm.nsysu.edu.tw

UDC

339.727 .22

(4-672EU)

Original

scientific

paper
Received:

03.08.2018

Accepted:

28.12.2018
Abstract: The aim of this paper is to examine the factors that explain the observed differences in inward foreign direct investment (FDI) performance between the peripheral southern eurozone countries (namely Greece and Portugal) and the eight Eastern EU members (Czech Republic, Estonia, Hungary, Latvia, Lithuania, Poland, Slovakia, and Slovenia) that joined in 2004. The empirical analysis, which is based on the estimation of a panel-econometric model during the 2004-2016 period, provides for Greece and Portugal policy relevant insights with respect to improving the international competitiveness and attracting more FDI inflows vis-a-vis Eastern EU countries, which have outperformed the two southern eurozone members. The results indicate that, among other factors, positive differences in labour costs and corporate tax rates between southern eurozone members and Eastern EU member states largely explain the observed differences in inward FDI performance among those two country groups. The higher labour costs and corporate taxation in Greece and Portugal exhibit a strong negative impact on their relative inward FDI performance vis-avis Eastern EU members. Furthermore, differences in economic openness and integration into vertical production networks also have a significant effect on inward FDI performance.

Keywords: Foreign Direct Investment; Inward FDI performance; Greece; Portugal; Eastern EU member states; Panel-econometric analysis.

JEL classification: F15; F21; F23; H25; H73 


\section{Introduction}

The successive steps of European integration - particularly the completion of the single European market in 1992 and the establishment of the EMU in 1999 brought with it deeper economic integration and the increase in the intra-EU mobility of firms, inducing an intensification of competition for firms and inward foreign direct investment (FDI) within the European Union. Among other things this has led also to a rising mobility and migration of national capital tax bases across the member states. These developments implied that the tax policies (with regard to corporate taxation) of the member countries would become more interdependent and create fiscal externalities, affecting thus a broad range of the members' national economic policies and the location of economic activities within the EU. It is a fact that this intensified competition for internationally mobile capital, which is supplied by multinational corporations (MNCs), among EU countries has been recently reflected by an intensified European tax competition the trend towards undercutting tax rates in order to attract firms from other EU locations.

For the peripheral southern eurozone member countries such as Greece and Portugal, inward FDI represents an important source of capital and a potential significant long-run growth engine, given the difficulties and economic crises these economies have experienced (especially Greece). However, since the 2004 EU enlargement, many of Eastern European members have attracted a considerable amount of FDI from western wealthy EU nations. Though Greece and Portugal are not high cost locations (in terms of labor cost and corporate tax burden) compared to some western and northern EU members, Eastern European countries exhibit much lower wages as well as lower corporate income taxation.

Thus a policy relevant question that arises is whether corporate tax and labour cost differentials between the two peripheral eurozone countries and Eastern EU members that joined in 2004, explain the observed differences in inward FDI performance among those two country groups. Furthermore, along with the above, information on other deterministic factors of FDI performance differences has also economic policy implications for the southern eurozone members. Such information would provide the knowledge to make their economies more competitive and enabling them to attract more FDI. Corporate tax rates are emphasised by the traditional tax competition literature with regards to attracting internationally mobile capital ${ }^{1}$, whilst low labour costs are at the centre of efficiency-seeking FDI motives with respect to labour (e.g. Dunning, 1980; Dunning and Lundan, 2008). However, there are other factors that have to be considered, such as those emphasised by the emerging New Economic Geography

${ }^{1}$ This literature has its origins from the so-called basic tax competition models of Zodrow and Mieszkowski (1986) and Wilson (1986). For an excellent presentation and review of the theoretical tax competition literature see for instance Wilson (1999). 
(NEG) literature (e.g. Krugman, 1991a,b, KrugmanandVenables, 1995a,b, Fujita, Krugman, andVenables, 1999) ${ }^{2}$ and other location factors (e.g. Silva and Lagoa, 2018; Vogiatzoglou, 2016; Corcoran and Gillanders, 2015; Blonigen and Piger, 2014). In other relatively more recent theoretical frameworks of the NEG, the models of Baldwin and Krugman (2004), Andersson and Forslid (1999), and Ludema and Wooton (1997), which explicitly analyse international corporate taxation issues and their effects on industry location, point out that tax differentials are counterbalanced by other factors and mechanisms that are important for agglomeration and that a "race to the bottom" of tax rates (as the conventional tax competition models predict) must not necessarily take place.

In this paper, by specifying an econometric model of bilateral inward FDI performance differences between the southern eurozone members and Eastern EU states, we examine the various factors that explain the observed FDI differences. The objective is to provide policy relevant information on the underlying determinants and assess their relative importance, which could guide policy makers to design policy measures to strengthen the competitiveness of Greece and Portugal vis-a-vis the Eastern EU members with respect to attracting FDI. We focus on corporate taxation, labour costs, and factors associated with the NEG literature. Eight Eastern EU member countries (which joined the EU in 2004) are included in the panel-data analysis during the 2004-2016 period.

The remainder of the paper is organised as follows. Section 2 describes the data and variables as well as the trends in inward FDI performance in Greece and Portugal vis-a-vis the eight Eastern EU member countries in our sample. Section 3 provides an overview of the empirical methodology and econometric model. Section 4 presents the empirical results. Finally, Section 5 summarises the most important findings and conclusions.

\section{Data, variables, and hypotheses}

The panel-data sample consists of the two southern eurozone member countries (Greece and Portugal) and eight Eastern EU members (Czech Republic, Estonia, Hungary, Latvia, Lithuania, Poland, Slovakia, and Slovenia) over the period 20042016.

We take as a measure of a country's inward FDI performance a country's FDI inflows per capita (in US dollars) in order to have a relative performance measure and avoid issues with country size differences (which the absolute amount of FDI would introduce). FDI inflows and relative FDI performance have been widely used in the

${ }^{2}$ This literature of the NEG framework has been initiated by Krugman's (1991a,b) pioneering work. For a good overview of the theoretical framework of the NEG see for instance Ottaviano and Puga (1998), Fujita, Krugman, andVenables (1999), and Neary (2001). 
literature (e.g. Jovanovic and Jovanovic, 2018; Benassy-Quere et al., 2004, Gropp and Kostial, 2000; 2001, Devereux and Griffith, 2002, Haufler and Stowhase, 2003).

Regarding the explanatory variables, the main interest of our econometric analysis lies in the tax policy differences (corporate tax rates), labour cost differences, as well as in various factors emphasised by the NEG framework. However, in order to take into account also other factors and have no omittedvariables bias problems with our econometric specification, we also include other independent variables which are considered to be important deterministic factors and function as control variables.

Thus, the factors considered in the empirical analysis include:

- Corporate tax rate (nominal statutory tax rate and effective tax rate);

- Unit labour cost;

- Degree of access and integration with international markets;

- Extent of participation in vertical production networks;

- Potential of the home market;

- Degree of the country's peripherality;

- Extent of a country's macroeconomic stability.

Following the arguments of the tax competition literature and conventional economic wisdom, the corporate tax rate is considered to exert a negative influence on firm attraction. The cost of labour in a country, which is proxied by the unit labour cost, is expected to exert a negative effect on inward FDI.

Given that an extraordinary open country to the international economy is likely to receive much more trade and FDI flows and that in many circumstances trade and FDI are complements, where the existence of the former increases the volume of the latter (see for instance, Markusen, 1998, Fontagne, 1999), the degree of access and integration of a country with international markets, which is proxied by the relative importance of total trade in the home economy - trade-GDP ratio (Benassy-Quereetal., 2004, GroppandKostial, 2000), is expected to be positively related to the volume of FDI inflows. Furthermore, the above openness indicator reflects the country's extent of access to large international markets, which is a factor emphasised by the NEG framework and constitutes an important determinant as regards a location's attractiveness.

Participation in global vertical production networks is an influential driving force of FDI (specifically vertical FDI) in the EU as well as in the world economy during the last two decades and its importance is constantly rising. A country with a large extent of participation in those global production networks and supply chains is expected to exhibit a higher FDI, as MNCs engage to a large degree in this type of international production and increasingly conduct vertical FDI. The relevant measure the authors use is the foreign value-added in domestic production, which is a widely used indicator for international production fragmentation and global value chains. 
The potential of the home market in terms of growth, which is proxied by the GDP growth rate, exerts a positive effect on industry location, as emphasised by the relevant theoretical literature (e.g. Krugman, 1980, 1991a,b) and empirical literature (e.g. Benassy-Quere et al., 2004, Gropp and Kostial, 2000). This variable is an important factor of FDI attraction, especially of the market-seeking FDI. In addition, the potential for growth of the home market is an important factor for MNCs which exhibit large scale economies in the production process (the home-market effect production concentrates and takes place in the large market in order to realise economies of scale and minimise transport and trade costs (Krugman, 1980, 1981, HelpmanandKrugman, 1985, Benassy-Quereetal., 2004), while it also plays an equally crucial role in the analytical framework of the NEG, where market size is endogenous and can induce circular processes of agglomeration (Krugman, 1991a,b, KrugmanandVenables, 1995a,b, Fujita, Krugman, andVenables, 1999).

Table 1. Definitions and data sources of the variables

\begin{tabular}{|c|c|}
\hline Variable & Description and Data Source \\
\hline$F D I D_{i j t}$ & $\begin{array}{l}\text { The difference in the FDI inflows per capita (in US dollars) between country } i \text { and } j \text {. Country } i \\
\text { includes the southern eurozone members (Greece, Portugal), and country } j \text { includes the eight } \\
\text { Eastern EU members. Data Source: United Nations FDI database. }\end{array}$ \\
\hline$T A X D_{i j t}$ & $\begin{array}{l}\text { The difference in the nominal (statutory) corporate tax rate between country } i \text { and } j \text {. Data } \\
\text { Source: Devereux et al. (2010); Spengel et al. (2015) }\end{array}$ \\
\hline EFFTAXD & $\begin{array}{l}\text { The difference in the average effective corporate tax rate between country } i \text { and } j \text {. Effective } \\
\text { rates are based on Devereux and Griffith (2003). Data Source: Devereux et al. (2010); } \\
\text { Spengel et al. (2015). }\end{array}$ \\
\hline \multicolumn{2}{|c|}{$\begin{array}{l}\text { LABCOSTD }_{i j} \text { The difference in the unit labor cost between country } i \text { and } j \text {. Data Source: European } \\
\text { Commission (2004). }\end{array}$} \\
\hline$O P E N D_{i j t}$ & $\begin{array}{l}\text { The difference in the openness indicator (X+M/GDP) between country } i \text { and } j \text {, where } X \text { is } \\
\text { exports, } M \text { is imports (in US dollars). Data Source: World Development Indicators, World } \\
\text { Bank. }\end{array}$ \\
\hline$V P N D_{i j t}$ & $\begin{array}{l}\text { The difference in an indicator (foreign value-added in domestic production) for a country's } \\
\text { extent of participation in vertical production networks. Data Source: OECD TiVA database. }\end{array}$ \\
\hline \multicolumn{2}{|c|}{$\begin{array}{l}\text { MARKETD } D_{i j t} \text { The difference in the GDP growth (as an indication of market growth potential) between } \\
\text { country } i \text { and } j \text {. Data Source: United Nations National Accounts Main Aggregates } \\
\text { Database. }\end{array}$} \\
\hline PERIPHD $D_{i j t}$ & $\begin{array}{l}\text { The difference in the Keeble et al. (1988) Peripherality index between country } i \text { and } j \text {. Data } \\
\text { Source: Own calculations of indices based on distance and GDP data by CEPII and United } \\
\text { Nations. }\end{array}$ \\
\hline$M A C R O S D$ & $\begin{array}{l}\text { The difference in a composite } 0-100 \text { index consisting of the inflation rate and the debt level } \\
\text { between country } i \text { and j.Data Source: Own calculations based on data from EUROSTAT, } \\
\text { Economy and Finance Statistics. }\end{array}$ \\
\hline
\end{tabular}


The last deterministic factor implied by the NEG framework in our econometric analysis is the degree of the country's peripherality within a country group (here the EU), which indicates the economic status of a country (location) and is proxied by the Peripherality index of Keeble et al. (1988). The extent of a country's peripherality is expected to exert a negative effect on the attraction of firms in that country.

Finally, the extent of a country's macroeconomic stability is considered to be a general factor that favours the attraction of FDI, as foreign investors trust more stable economies. Our proxy for macroeconomic stability is a composite index (ranging from 0 to 100) consisting of the inflation rate and the debt level, which is reversed so that higher values indicate macroeconomic stability. The definitions of all variables (as they enter the regression model in bilateral differences) as well as the data sources are presented in Table 1.

Before proceeding with the presentation of the empirical methodology, we briefly examine some trends and patterns with respect to inward FDI conformance in Greece, Portugal, and the eight Eastern EU member states: Czech Republic, Estonia, Hungary, Latvia, Lithuania, Poland, Slovakia, and Slovenia. Figure 1 shows the FDI inflows per capita (in US dollars) during 2004-2016 for Greece, Portugal, and the average of eight Eastern EU members. As it is evident, on average, the inward FDI performance of Eastern EU member countries is better than of the two southern peripheral eurozone members. Greece experienced a sharp decline due to the economic and debt crisis that struck the country, but has recently showed an upward trend in inward FDI. Table 2 reports the three top Eastern EU countries in inward FDI performance for selected years over the study period 20042016. As it can be seen, Estonia and Slovakia are mostly the number one inward FDI performing countries (in relative terms, that is FDI expressed in per capita). The Czech Republic is found to represent the second best performing country in most years, whilst Lithuania and Slovenia appear also as in the top-3 in certain years.

Figure 1. Inward FDI per capita (US dollars), 2004-2016

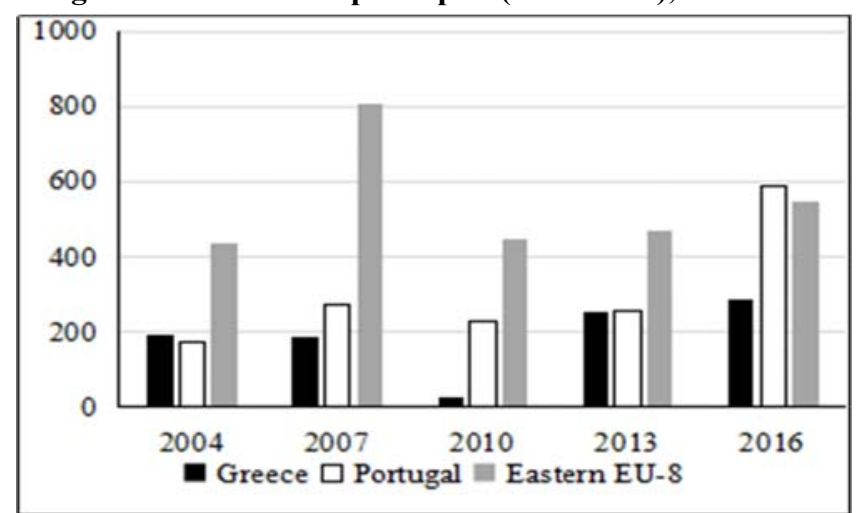

Source: Own compilation based on United Nations FDI database 
Table 2. Top-3 Eastern EU countries of inward FDI performance

\begin{tabular}{llllll}
\hline No. & 2004 & 2007 & 2010 & 2013 & 2016 \\
\hline 1 & Slovakia & Estonia & Estonia & Slovakia & Estonia \\
2 & Estonia & Latvia & Czech Rep. & Slovenia & Czech Rep. \\
3 & Czech Rep. & Czech Rep. & Lithuania & Lithuania & Slovenia \\
\hline
\end{tabular}

Source: Own compilation based on United Nations FDI database.

\section{Econometric methodology}

Since the aim of our econometric analysis to examine the factors that account for the observed differences in inward FDI performance between Greece/Portugal and Eastern EU members, we construct an empirical model that considers the observed bilateral differences in various variables between Greece/Portugal and each of the eight Eastern EU members, and relate those differences with the observed bilateral inward FDI performance differences.

All of the variables (dependent and independent) enter the panel-data regression model in the form of bilateral differences between country $i$ (either Greece or Portugal) and $j$ (each of eight Eastern EU member countries in our sample). Thus, the cross-section dimension of the panel data structure is represented by country pairs $i j$ and the time dimension by the annual observations during the period 2004-2016. This approach is used whenever the econometric analysis specifically aims at examining bilateral differences. In the context of our analysis this refers to analyzing the factors that explain the observed bilateral differences in inward FDI performance between the two southern peripheral eurozone members and Eastern EU countries.

As we have two alternative measures of corporate taxation (the nominal statutory corporate tax rate and average effective corporate tax rate), we estimate two baseline panel data models, which can be represented as follows:

$$
\begin{aligned}
& \text { FDID }_{i j t}=\beta_{0}+\beta_{1} \text { TAXD }_{i j t}+\beta_{2} \text { LABCOSTD }_{i j t}+\beta_{3} \text { OPEND } \\
& i j t \\
& +\beta_{5} \text { MARKETD }_{i j t}+\beta_{6} \text { PERIPHDD }_{i j t}+\beta_{7} \text { MACROSD }_{i j t}+\mu_{i j}+v_{t}+\varepsilon_{i j t} \\
& \text { FDID }_{i j t}=\beta_{0}+\beta_{1} \text { EFFTAXD }_{i j t}+\beta_{2} \text { LABCOSTD }_{i j t}+\beta_{3} O P E N D_{i j t}+\beta_{4} V P N D_{i j t} \\
& +\beta_{5} \text { MARKETD }_{i j t}+\beta_{6} \text { PERIPHD }_{i j t}+\beta_{7} \text { MACROSD }_{i j t}+\mu_{i j}+v_{t}+\varepsilon_{i j t}
\end{aligned}
$$

where $\mu_{i j}, v_{t}$, and $\varepsilon_{i j t}$ refer to cross-section (country-pair) fixed effects, time specific fixed effects, and the regression's error term, respectively. 
As unobserved cross-section (country-pair) effects surely play a significant role in the context of our econometric model, the authors estimate a fixed-effects panel data model. In addition, since temporal effects might be present (specific shocks in certain years, such as economic crises or common macroeconomic shocks and events in certain time periods influencing the impact of the explanatory variables), year dummies are included. The econometric model, thus, takes into account and controls for both cross-section specific and time specific fixed effects. Hence, panel-regression equations (1) and (2) are estimated by the panel fixed-effects estimator.

Explanatory variables such as differences in economic openness (OPEND), in the degree of participation in vertical production networks $(V P N D)$, in market growth potential (MARKETD), and macroeconomic stability (MACROSD) between southern eurozone countries $(i)$ and Eastern EU members $(j)$ are expected to exhibit a positive sign, as positive differences in those variables indicate that country $i$ has a higher value compared to country $j$, and thus country $i$ is expected to exhibit a higher value of inward FDI performance (positive bilateral difference in FDI inflows) because the above mentioned factors affect FDI positively. On the other hand, variables such as corporate taxation (TAXD or EFFTAXD), labour costs ( $L A B C O S T)$, and a country's peripherality from the EU economic center $(P E R I P H D)$ are expected to show a negative coefficient sign.

Positive differences in those factors (which affect FDI inflows negatively) indicate that country $i$ has a higher value compared to country $j$, and consequently $i$ is expected to exhibit a lower inward FDI performance compared to $j$ (resulting in negative bilateral differences in FDI inflows). For instance, if southern eurozone members exhibit higher tax rates or labour costs (which they actually do over our sample period) compared to Eastern EU countries, they should be expected to exhibit lower FDI inflows compared to Eastern EU members (which actually occurs during all years with almost every Eastern country within our sample over 2004-2016).

Finally, in order to evaluate the relative importance and impact of each explanatory variable, all variables have been transformed into standardised variables before estimation. Thus, the estimated regression parameters $\left(\beta_{1}, \beta_{2}, \beta_{3}, \beta_{4}\right.$, $\beta_{5}, \beta_{6}$, and $\beta_{7}$ ) represent standardised regression coefficients, also known as beta coefficients. Those beta regression coefficients are unit free (not affected by the underlying measurement unit of the variable) and show the magnitude of the impact of an explanatory variable on the dependent variable in relative terms. In particular, the beta coefficient indicates the number of standard deviations the dependent variable changes when the independent variable changes one standard deviation. 


\section{Empirical results and discussion}

In Tables 3 and 4 the authors report the estimation results of the determinants of inward FDI performance differences between the two southern peripheral eurozone members and eight Eastern EU countries with nominal corporate tax rates and effective corporate tax rates, respectively.

Turning first to the regression model with nominal corporate taxation, it is evident that all variables show the expected coefficient sign and are statistically significant at the $1 \%$ level, with the exception of macroeconomic stability which is found to be significant at the 5\% level. Most importantly, the econometric results confirm that positive differences in tax rate differentials and labour cots differentials among Greece/Portugal and Eastern EU members empirically explain the negative differences in inward FDI performance between those two country groups. Higher taxes and labour costs in Greece and Portugal compared to Eastern EU countries explain the lower inward FDI performance of the two southern eurozone countries relative to Eastern EU members.

Table 3. Determinants of inward FDI performance differences (with nominal corporate tax rates)

\begin{tabular}{ccc}
\hline Variables & Coefficient & P-value \\
\hline TAXD & -0.3874 & 0.000 \\
LABCOSTD & -0.9140 & 0.000 \\
OPEND & 0.7005 & 0.000 \\
VPND & 0.9820 & 0.000 \\
MARKETD & 0.5805 & 0.006 \\
PERIPHD & -1.1145 & 0.000 \\
MACROSD & 0.3443 & 0.024 \\
Statistics & & \\
$R^{2}$ & 0.732 & \\
F-test & 9.467 & 0.000 \\
$n T$ & 208 & \\
\hline
\end{tabular}

Source: Own econometric estimation results of equation (1).

Furthermore, the peripherality is also found to exert a negative effect on FDI inflows, as expected. A higher extent of peripherailty of Greece and Portugal from the wealthy EU countries of central, west, and northern EU (relative to Eastern countries which are close to central and west EU nations that represent the EU centre in terms of economic output of the EU) results, on average, in lower inward FDI performance compared to eight Eastern EU states. As expected the extent of economic openness and participation in vertical production networks as well as macroeconomic stability exerts a positive effect on inward FDI. In terms of our 
model this can imply that positive bilateral differences between $i$ and $j$ in those factors result in positive bilateral differences between $i$ and $j$ in inward FDI performance, or equivalently that negative bilateral differences between $i$ and $j$ in those factors result in negative bilateral differences between $i$ and $j$ in inward FDI, and consequently the coefficient sign is positive.

Table 4: Determinants of Inward FDI Performance differences (with effective corporate tax rates)

\begin{tabular}{ccc}
\hline Variables & Coefficient & P-value \\
\hline EFFTAXD & -0.4942 & 0.000 \\
LABCOSTD & -0.9347 & 0.000 \\
OPEND & 0.6842 & 0.000 \\
VPND & 1.0770 & 0.000 \\
MARKETD & 0.5954 & 0.003 \\
PERIPHD & -1.1787 & 0.000 \\
MACROSD & 0.3497 & 0.022 \\
Statistics & & \\
$R^{2}$ & 0.751 & \\
F-test & 10.260 & 0.000 \\
$n T$ & 208 & \\
\hline
\end{tabular}

Source: Own econometric estimation results of equation (2).

The second regression model generates the same overall picture with respect to the determinants, but has a slightly better overall model fit as well as higher coefficient estimates. This is particularly true for the corporate tax rate which in this model refers to the effective tax rate. The negative beta coefficient of the EFFTAXD variable indicates that a one standard deviation increase in the bilateral difference in the effective corporate tax rate between the southern eurozone members and Eastern EU countries results in a around 0.49 standard deviation decline in the dependent variable, that is, in a decline in the inward FDI performance of Greece/Portugal vis-a-vis Eastern EU members. The beta coefficient of the labour cost variable is even higher, suggesting that when labour cost differentials increase by one standard deviation, the inward FDI performance of the two southern eurozone countries relative to Eastern EU states declines by about 0.93 standard deviations. This is a rather strong effect. The most important determinant of inward FDI performance differences is found to be the peripherailty variable with a beta coefficient of around 1.17. As this peripherality depends on the location of a country relative to the EU core, it does not represent a policy variable and the government cannot do anything to change the extent of peripherality. In this sense, it has less policy relevance compared to other factors, especially corporate taxation and labour costs. 


\section{Conclusion}

This paper has examined the bilateral differences in inward FDI performance between the two southern peripheal eurozone countries (Greece and Portugal) and eight Eastern EU member states (the Czech Republic, Estonia, Hungary, Latvia, Lithuania, Poland, Slovakia, and Slovenia) that joined the European Union in 2004. More specifically, in addition to tracing the trends in differential performance of inward FDI across our sample of countries, we have analysed the determinants that account and empirically explain the observed differences in FDI inflows among the two country groups over the 2004-2016 period. For this purpose a paneleconometric model has been specified and estimated, with which policy relevant information for Greece and Portugal has been revealed.

The empirical findings have indicated that differences in labour costs and corporate tax rates between southern eurozone members and Eastern EU countries explain the differences in inward FDI performance among those two country groups. More specifically, the aforementioned factors (especially labour costs) have a large negative effect on the relative inward FDI performance of Greece and Portugal vis-a-vis Eastern EU members. Thus, a policy implication that arises for southern eurozone countries is that FDI performance relative to Eastern EU countries could be improved by making the economies of Greece and Portugal more competitive in terms of corporate tax burden and labor costs. It has to be mentioned though that the latter might not be possible, as it is a socially and politically sensitive issue.

However, instead of decreasing the labour cost, a policy measure could be to maintain stable wages and refrain from introducing extra and excessive labour and employment related costs to firms and specifically to MNCs. Given that during the last years the tax rates have increased (especially in Greece) in order to cope with budget deficits and economic crises, a policy of having a more business friendly corporate tax system and lower burden seems to be a sensible measure to be taken. As the results also showed that a country's economic openness as well as participation in international production networks affects positively the attraction of FDI inflows, Greece and Portugal could in addition take active measures to increase the openness and integration of their economies with European and global production networks. This might require the introduction of special incentives and economic zones targeted specifically at multinational firms engaging in international production sharing. 


\section{References}

Andersson F. \& R. Forslid (1999). Tax Competition and Economic Geography (CEPR Discussion Paper, No. 2220), London: Centre for Economic Policy Research.

Baldwin, R. \& Krugman, P. (2004). Agglomeration, Integration and Tax Harmonization. European Economic Review, 48(1), 1-23.

Benassy-Quere, A., Fontagne, L. \& Lareche-Revil, A. (2004). Foreign Direct Investment and the Prospects for Tax-Coordination in Europe (CEPII Working Paper), Paris: CEPII.

Blonigen, B.A. \& Piger, J. (2014). Determinants of foreign direct investment.Canadian Journal of Economics, 47(3), 775-812.

Corcoran, A. \& Gillanders, R. (2015). Foreign direct investment and the ease of doing business. Review of World Economics, .151(1), 103-126.

Devereux, M. \& Griffith, R. (2002). The Impact of Corporate Taxation on the Location of Capital: A Review. Swedish Economic Policy Review, 9(1), 79-102.

Devereux, M. \&Griffith, R. (2003). Evaluating tax policy for location decisions. International Tax and Public Finance, 10(1), 107-126.

Dunning, J. H. (1980). Toward an eclectic theory of international production: Some empirical tests. Journal of International Business Studies, 11(1), 9-31.

Dunning, J. \&Lundan, S. (2008). Institutions and the OLI paradigm of the multinational enterprise. Asia Pacific Journal of Management, 25(4), 573-593.

Eggert, W. \& Genser, B. (2004). Corporate Tax Harmonization in the EU: Status and Perspectives (CEsifo Discussion Paper), Munich: CEsifo.

European Commission (2004), Broad Economic Policy Guidelines, (The 2004 update), European Economy, No. 4/2004.

Fontagne, L. (1999). Foreign Direct Investment and International Trade: Complements or Substitutes? (STI Working Paper No. 99/3), Paris: Organisation for Economic Cooperation and Development, Paris.

Fujita, M., Krugman, P. \& Venables, A.J. (1998). The Spatial Economy: Cities, Regions and International Trade. Cambridge, MA: MIT Press.

Gropp, R. \& Kostial, K. (2000). The Disappearing Tax Base: Is Foreign Direct Investment Eroding Corporate Income Taxes?, (ECB Working Paper, No. 31), Frankfurt: European Central Bank.

Gropp, R. \& Kostial, K. (2001). FDI and Corporate Tax Revenue: Harmonization or Competition? Finance and Development, 38(2), International Monetary Fund, Washington.

Haufler, A. and Stowhase, S. (2003), "Taxes as a Determinant for Foreign Direct Investment in Europe”, CESifo DICE Report, 2/2003, pp. 45-51.

Helpman, E. \& Krugman, P. (1985). Market Structure and Foreign Trade. Cambridge, MA: MIT Press.

Jovanovic, B. \& Jovanovic, B. (2018). Ease of doing business and FDI in the ex-socialist countries. International Economics and Economic Policy, 15(3), 587-627.

Krugman, P. (1980). Scale Economies, Product Differentiation, and the Pattern of Trade. American Economic Review, 70(5), 950-959.

Krugman, P. (1981). Intraindustry Specialization and the Gains from Trade. Journal of Political Economy, 89(5), 959-973.

Krugman, P. (1991a). Increasing Returns and Economic Geography. Journal of Political Economy, 99(3), 483-499. 
Krugman, P. (1991b) Geography and Trade. Cambridge, MA: MIT Press.

Krugman, P. \& Venables, A.J. (1995a). Globalization and the Inequality of Nations. Quarterly Journal of Economics. 110(4), 857-880.

Krugman, P. \& Venables, A.J. (1995b). The Seamless World: A Spatial Model of International Specialization (NBER Discussion Paper, No. 5220), Cambridge, MA: National Bureau of Economic Research.

Lannoo K. and Levin M. (2002), An EU Company without an EU Tax? A Corporate Tax Action Plan for Advancing the Lisbon Process, CEPS Research Report.

Ludema, R. \& Wooton, I. (1998). Economic Geography and the Fiscal Effects of Regional Integration (CEPR Discussion Paper, No. 1822), London: Centre for Economic Policy Research.

Markusen, J. (1998). Multinational Firms, Location and Trade. The World Economy, 21(6), 733-756.

Neary, J.P. (2001). Of Hype and Hyperbolas: Introducing the New Economic Geography. Journal of Economic Literature, 39(2), 536-561.

Ottaviano, G. \& Puga, D. (1998). Agglomeration in the Global Economy: A Survey of the New Economic Geography. World Economy, vol. 21(6), 707-731.

Silva, T. and Lagoa, S. (2018), Corporate Taxes and The Location of FDI in Europe: The Importance Economic Integration and Project Characteristics. Economic Annals, 63(217), 39-74.

UNCTAD (1996). World Investment Report 1996: Investment, Trade and International Policy Arrangements. New York and Geneva: United Nations Conference on Trade and Development.

UNCTAD (2000). World Investment Report 2000: Cross-border Mergers and Acquisitions and Development. New York and Geneva: United Nations Conference on Trade and Development.

UNCTAD (2004). World Investment Report 2004: The Shift Towards Services. New York and Geneva: United Nations Conference on Trade and Development.

Venables, A.J. (1996). Equilibrium Locations of Vertically Linked Industries. International Economic Review, 37(2), 341-359.

Vogiatzoglou, K. (2016). Ease of Doing Business and FDI Inflows in ASEAN. Journal of Southeast Asian Economies, 33(3), 343-363.

Wilson, J.D. (1986). A Theory of Interregional Tax Competition. Journal of Urban Economics, 19(3), 296-315.

Wilson, J.D. (1999). Theories of Tax Competition. National Tax Journal, 52(2), 269-304.

Zodrow, G. \&Mieszkowski, P. (1986). Pigou, Tiebout, Property Taxation, and the Underprovision of Local Public Goods. Journal of Urban Economics, 19(3), 356-370. 


\section{RAZLIKE U PERFORMANSAMA ULAGANJA U VIDU SDI IZMEĐU JUŽNE EVROZONE I ČLANOVA ISTOČNE EU: PANEL ANALIZA ZA PERIOD 2004-2016. GODINA}

Apstrakt: Cilj ovog rada je da ispita faktore koji objašnjavaju uočene razlike u performansama unutrašnjih direktnih stranih investicija između perifernih zemalja južne Evrozone (Grčka i Portugalija) i osam zemalja istočne EU (Češka, Estonija, Mađarska, Letonija, Litvanija, Poljska, Slovačka i Slovenija) koje su pristupile 2004 godine. Empirijska analiza, koja se zasniva na proceni ekonometrijskog panel modela tokom perioda 2004-2016, pruža politički relevantne uvide Grčkoj i Portugau u pogledu poboljšanja međunarodne konkurentnosti i privlačenje većeg priliva SDI u odnosu na zemlje istočne EU, koje su nadmašile dve članice južne Evrozone. Rezultati pokazuju da, između ostalih faktora, pozitivne razlike u troškovima rada i stopama poreza na dobit između članica južne Evrozone i zemalja istočne EU uglavnom objašnjavaju uočene razlike u performansama unutarnjih FDI među tim grupama zemalja. Veći troškovi rada i oporezivanje korporacija u Grčkoj i Portugalu pokazuju snažan negativan uticaj na njihovu relativnu dinamiku direktnih stranih investicja u odnosu na istočne članice EU. Štaviše, razlike u ekonomskoj otvorenosti i integraciji u vertikalne proizvodne mreže takođe imaju značajan uticaj na performanse unutrašnjih SDI.

Ključne reči: direktne strane investicje, učinak unutrašnjih SDI, Grčka, Portugal, zemlje istočne EU, ekonometrijska panel analiza.

\section{Author's biography}

Klimis Vogiatzoglou, PhD, holds a BSc in Economics, a Master's in International Economics, and a PhD in International Business. He is an active academic teacher and researcher, and has previously held several academic as well as policy research positions at various institutions in Europe and Asia. Though he mainly works in academia as a research professor, he's also actively engaged in the consulting industry as professional economist and market analyst. He specialises in issues related to international business, international economics, and development economics. In addition to European countries, his current research revolves around emerging and developing economies from the Asia-Pacific region. 